\title{
Effect of cyanide by sodium nitroprusside (SNP) application on germination, antioxidative system and lipid peroxidation of Senna macranthera seeds under saline stress ${ }^{1}$
}

\author{
Aparecida Leonir da Silva ${ }^{2 *}$, Daniel Teixeira Pinheiro ${ }^{3}$, Eduardo Euclydes de \\ Lima e Borges ${ }^{4}$, Laércio Junio da Silva ${ }^{3}$, Denise Cunha Fernandes dos Santos Dias ${ }^{3}$
}

\begin{abstract}
The effects of NO donors on germination under saline stress have been much investigated for many species, however, there are reports that the effect caused by donors are effects of cyanide present. The aim of this study was to evaluate the effects of sodium nitroprusside (SNP) on germination, antioxidative system and lipid peroxidation of Senna macranthera seeds under saline stress. The osmotic potentials of -0.4 and $-0.5 \mathrm{MPa}$ of $\mathrm{NaCl}$ were used, as well as the concentration of $100 \mu \mathrm{M}$ of sodium nitroprusside, inactive sodium nitroprusside. Germination rate, imbibition curves, antioxidant enzyme activity, lipid peroxidation, and protein content were evaluated. Similar effects were observed for sodium nitroprusside and inactive sodium nitroprusside, indicating that these effects were related to the release of the cyanide present in sodium nitroprusside. The sodium nitroprusside (SNP) improves the germination of Senna macranthera seeds under salt stress conditions, through release of cyanide. The cyanide favored germination, reducing lipid peroxidation and increasing the activity of the antioxidant enzymes.
\end{abstract}

Index terms: antioxidant enzymes, $\mathrm{NaCl}$, nitric oxide, salinity.

\section{Efeito do cianeto via aplicação de nitroprussiato de sódio (SNP) na germinação, no sistema antioxidativo e na peroxidação lipídica de sementes de Senna macranthera sob estresse salino}

\begin{abstract}
RESUMO - Os efeitos dos doadores de NO na germinação sob estresse salino têm sido muito investigados para muitas espécies, entretanto, há relatos de que o efeito causado pelos doadores são efeitos do cianeto presente. O objetivo deste estudo foi avaliar os efeitos do SNP na germinação, no sistema antioxidativo e na peroxidação lipídica de sementes de Senna macranthera sob estresse salino. Foram utilizados os potenciais osmóticos de - 0,4 e - $0,5 \mathrm{MPa}$ de $\mathrm{NaCl}$, e a concentração de $100 \mu \mathrm{M}$ de nitroprussiato de sódio, nitroprussiato de sódio inativo. A taxa de germinação, as curvas de embebição, a atividade das enzimas antioxidantes, a peroxidação lipídica e o teor de proteína foram analisados. Efeitos semelhantes foram observados para o nitroprussiato de sódio e o nitroprussiato de sódio inativo, indicando que os efeitos foram relacionados à liberação do cianeto presente no nitroprussiato de sódio. O SNP favoreceu a germinação das sementes de Senna macranthera sob estresse salino devido à liberação de cianeto. O cianeto foi benéfico para a germinação reduzindo a peroxidação lipídica e aumentando a atividade das enzimas antioxidantes.
\end{abstract}

Termos para indexação: enzimas antioxidantes, $\mathrm{NaCl}$, óxido nítrico, salinidade.

\section{Introduction}

The damage caused by saline stress ranges from damage to proteins, lipids and nucleic acids to changes in photosynthesis and respiration of plants, affecting plant growth and development and this is a problem that occurs worldwide

${ }^{4}$ Departamento de Engenharia Florestal, Universidade Federal de Viçosa, 36570-900 - Viçosa, MG, Brasil.

*Corresponding author<aparecidaleonir@gmail.com> 
(Manai et al., 2014). Salinity also affects germination, a fundamental stage in plant establishment, making it difficult to absorb water due to the reduction of the osmotic potential of the medium and facilitating the entry of toxic amounts of $\mathrm{Na}^{+}$ and $\mathrm{Cl}^{-}$ions into seeds during immersion (Simaei et al., 2012).

Toxicity through excess of ions causes not only osmotic stress but also an increase in production of reactive oxygen species (ROS) can lead to oxidative damages in various cellular components such as proteins, lipids, and DNA, interrupting vital cellular functions of plants (Gupta and Huang, 2014). One of the mechanisms seeds use to overcome oxidative stress is the action of antioxidant enzymes, such as superoxide dismutase (SOD), catalase (CAT), peroxidase (POX), and ascorbate peroxidase (APX), that perform important functions in eliminating and neutralizing the ROSs produced under salt stress (Seckin et al., 2010).

Nitric oxide (NO) is one of the most studied bioactive molecules being a free radical produced from L-arginine, a toxic, inorganic, colorless gas with seven nitrogen and eight oxygen electrons. NO has an important function in plant growth and development, in seed germination, primary and lateral root growth, pollen tube growth regulation, flowering, fruit ripening, senescence, defense response and abiotic stresses, and participate in the signalling molecule in different intracellular processes (Nasibi and Kalantari, 2009; Corpas et al., 2011).

The participation of NO in the mechanism of response to salinity stress has been also reported, although the information available can sometimes be contradictory, depending on the plant species and the severity of the salinity treatment (Begara-Morales et al., 2014).

Various studies have shown the positive effect of nitric oxide on increasing germination of seeds under different types of stress. NO under salt stress conditions in plants modulates ROS production and reinforces the activity of antioxidant enzymes (Singh et al., 2008). This is due to an increase in the activity of antioxidant enzymes, such as superoxide dismutase (SOD) and catalase (CAT) (Kopyra and Gwóz'dz', 2003).

However, there are studies that demonstrate the positive effect on germination caused by nitric oxide donors is not from nitric oxide, as in a study to overcome Arabidopsis seed dormancy, where the overcome of dormancy was related to cyanide (Bethke et al., 2006). The same was observed in seeds of Clitoria ternatea and Rhyncosia minima (Mullick and Chatterji, 1967). Small signaling molecules (toxic in high concentration) play important role in dormancy alleviation and are under severe control of antioxidant system. The authors propose that ROS, reactive nitrogen species and hydrogen cyanide at accurate level are essential in the seed germination and all together play the important role as developmental regulators (Krasuska and Gniazdowska, 2012).

In a previously study with of Senna macranthera (DC. ex Collad.) H. S. Irwin \& Barneby, it was observed that the application of SNP in conjunction with saline stress is the best method to recover the germination of these seeds. These effects were similar to those brought about by the sodium nitroprusside treatment and were also observed in the treatments with inactive sodium nitroprusside and ferrocyanide, indicating that the effects observed were related to release of the cyanide present in the sodium nitroprusside (Silva et al., 2018).

Based on these promising results of recovery of $S$. macranthera seeds under salt stress with sodium nitroprusside (SNP), the aim of this study was to evaluate the effects of the cyanide trough application of sodium nitroprusside (SNP) on germination and the antioxidative system of seeds under salt stress.

\section{Material and Methods}

For all tests the seeds of $S$. macranthera were mechanically scarified with number 100 sandpaper on the side opposite the hilum to break the physical dormancy. Then they were treated with CAPTAN fungicide at $0.2 \%\left(150 \mathrm{~g} .100 \mathrm{Kg}^{-1}\right.$ of seeds $)$. Two concentrations of $\mathrm{NaCl}$ osmotic potentials $(-0.4$ and -0.5 $\mathrm{MPa}$ ) were selected, causing a reduction of about $50 \%$ in seed germination (Silva et al., 2015). Saline stresses of -0.4 and -0.5 MPa were applied in conjunction with $100 \mu \mathrm{M}$ SNP, $100 \mu \mathrm{M}$ inactive SNP (48 h of exposure to light) and pure water (control) that are efficient in the recovery of stress (Silva et al., 2018).

Germination: four replications of 50 seeds were used. The seeds were placed to germinate in a seed incubator at $25{ }^{\circ} \mathrm{C}$ with an $8 \mathrm{~h}$ photoperiod for 7 days. In all treatments, the seeds were kept in rolls of paper towel moistened with a volume of solution or of water equal to 2.5 times the weight of the dry paper under the conditions described above. Were evaluated the number of germinated seeds (with primary root of at least $2 \mathrm{~mm}$ length), and the percentage of germinated seeds was calculated.

Imbibition curve: imbibition curves were established for the treatments that were previously selected. The seeds were scarified mechanically or not scarified (control), placed in paper towel, and moistened with water at the proportion of 2.5 times the weight of the dry paper. The tests were conducted in four replications of 25 seeds for scarified seeds and for the control. The weight of the seeds was monitored every 60 minutes up to $12 \mathrm{~h}$, every $3 \mathrm{~h}$ up to $84 \mathrm{~h}$, every $6 \mathrm{~h}$ up to $108 \mathrm{~h}$, and every $12 \mathrm{~h}$ up to $216 \mathrm{~h}$, until root protrusion occurred in $50 \%$ of the seeds.

Antioxidant enzyme activity: for determination of the activity of the superoxide dismutase (SOD), catalase 
(CAT), peroxidase (POX), and ascorbate peroxidase (APX) enzymes, the seeds were placed to germinate in the treatments described above. At 0, 24, 48, and $72 \mathrm{~h}$ after sowing, the embryos (cotyledons and embryonic axis) were extracted, frozen in liquid nitrogen, and stored at $-20{ }^{\circ} \mathrm{C}$ until the time of evaluation. Crude enzyme extracts were obtained through maceration of $0.1 \mathrm{~g}$ of embryos in liquid nitrogen, followed by the addition of $2 \mathrm{~mL}$ of extraction medium, potassium phosphate buffer $(0.1 \mathrm{M}$; $\mathrm{pH} 6.8)$, containing ethylenediamine tetraacetic acid (EDTA) $(0.1 \mathrm{mM})$, phenylmethylsulfonyl fluoride (PMSF) $(1.0 \mathrm{mM})$, and $1 \%$ polyvinylpolypyrrolidone (PVPP) (w/v) (Peixoto et al., 1999). The homogenized mixture was centrifuged at $19,000 \mathrm{~g}$ for $15 \mathrm{~min}$. at $4^{\circ} \mathrm{C}$.

SOD activity: $30 \mu \mathrm{L}$ of crude enzyme extract to $2.97 \mathrm{~mL}$ of reaction medium, composed of $50 \mathrm{mM}$ sodium phosphate buffer, $\mathrm{pH} 7.8$, containing $13 \mathrm{mM}$ methionine, $75 \mu \mathrm{M}$ nitro blue tetrazolium (NBT), $0.1 \mathrm{mM}$ EDTA, and $2 \mu \mathrm{M}$ riboflavin (Del Longo et al., 1993). The reaction was conducted at $25^{\circ} \mathrm{C}$ in a reaction chamber lighted. After $5 \mathrm{~min}$ of exposure, lighting was interrupted, and blue formazan, produced by the photoreduction of the NBT, was measured by absorbance at $560 \mathrm{~nm}$. The value of absorbance of a reaction medium equal to the previous one, but kept in the dark for the same period, used as a blank and was subtracted from the reading of each sample that received lighting (Giannopolitis and Ries, 1977). A unit of SOD was defined as the amount of enzyme necessary to inhibit photoreduction of the NBT by $50 \%$ (Beauchamp and Fridovich, 1971). The result was expressed in $\mathrm{U} \mathrm{min}^{-1} \cdot \mathrm{mg}^{-1}$ protein.

CAT activity: $30 \mu \mathrm{L}$ of crude enzyme extract to 2.97 $\mathrm{mL}$ of reaction medium, composed of $50 \mathrm{mM}$ potassium phosphate buffer, $\mathrm{pH} 7.0$, and12.5 $\mathrm{mM} \mathrm{H}_{2} \mathrm{O}_{2}$ (adapted from Havir and McHale, 1987). The decrease in absorbance at $240 \mathrm{~nm}$ at $25{ }^{\circ} \mathrm{C}$ was measured during the first minute of reaction. Enzyme activity was calculated using the molar extinction coefficient of $36 \mathrm{M}^{-1} \mathrm{~cm}^{-1}$ (Anderson et al., 1995), and the result was expressed in $\mu \mathrm{mol} \mathrm{min}{ }^{-1} . \mathrm{mg}^{-1}$ protein.

POX activity: $100 \mu \mathrm{L}$ of crude enzyme extract to $2.90 \mathrm{~mL}$ of reaction medium, composed of $25 \mathrm{mM}$ potassium phosphate buffer, $\mathrm{pH}$ 6.8, $20 \mathrm{mM}$ pyrogallol, and $20 \mathrm{mM} \mathrm{H}_{2} \mathrm{O}_{2}$ (adapted from Kar and Mishra, 1976). Production of purpurogallin was measured through increase of absorbance at $420 \mathrm{~nm}$ at $25^{\circ} \mathrm{C}$. Enzyme activity was calculated using the molar extinction coefficient of $2.47 \mathrm{M}^{-1} \mathrm{~cm}^{-1}$ (Maehley and Chance, 1955), and the result was expressed in $\mu \mathrm{mol} \mathrm{min}^{-1}$. $\mathrm{mg}^{-1}$ protein.

APX activity: $50 \mu \mathrm{L}$ of crude enzyme extract to $2.95 \mathrm{~mL}$ of reaction medium composed of potassium phosphate buffer (50 mM, pH 7.8), $0.5 \mathrm{mM}$ ascorbic acid, $0.1 \mathrm{mM}$ EDTA, and $1.2 \mathrm{mM} \mathrm{H}_{2} \mathrm{O}_{2}$. Decrease in absorbance at $290 \mathrm{~nm}$ was observed during the first minute at $25^{\circ} \mathrm{C}$. Enzyme activity was calculated using the $2.8 \mathrm{mM}^{1} . \mathrm{cm}^{-1}$ molar extinction coefficient and the result was expressed in $\mu \mathrm{mol} \mathrm{min}{ }^{-1} . \mathrm{mg}^{-1}$ protein.

Lipid peroxidation: samples of $0.2 \mathrm{~g}$ of $S$. macranthera seed embryo were homogenized with $2 \mathrm{~mL}$ of $0.1 \%(\mathrm{w} / \mathrm{v})$ TCA and centrifuged at $12,000 \mathrm{~g}$ for 5 minutes. From each sample, $1 \mathrm{~mL}$ of the supernatant was removed and $3 \mathrm{~mL}$ of $0.5 \%(\mathrm{w} / \mathrm{v})$ TBA and $20 \%(\mathrm{w} / \mathrm{v})$ TCA were added. The mixture was incubated in hot water at $90{ }^{\circ} \mathrm{C}$ for 35 minutes, and the reaction was interrupted in an ice bath for 10 minutes. After that, the samples were centrifuged at 10,000 $g$ for 5 minutes and a spectrophotometer reading was taken from the supernatant at two wavelengths, $532 \mathrm{~nm}$ and 600 $\mathrm{nm}$. The molar extinction coefficient of $155 \mathrm{mM}^{-1} \cdot \mathrm{cm}^{-1}$ was used to quantify the concentration of the lipid peroxides, and the results were expressed in nmol MDA g ${ }^{-1}$ (Heath and Packer, 1968).

Protein content: protein content was determined using bovine serum albumin (BSA) as a standard (Bradford, 1976). Enzyme extract in the amount of $50 \mu \mathrm{L}$ was used with the addition of $1 \mathrm{~mL}$ of Bradford reagent, followed by shaking. After 20 minutes, the absorbance of the sample was read in a spectrophotometer at $595 \mathrm{~nm}$.

Statistical analyses: the data on enzymatic activity, protein content, and lipid peroxidation were subjected to analysis of variance and the means of the treatments were compared by the Tukey test at $5 \%$ probability. The trials were conducted in a completely randomized design in a factorial arrangement with six treatments (salt stress, water, stress + SNP, SNP, inactive SNP, and stress + inactive SNP) $x$ four soaking times $(0,24,48$, and $72 \mathrm{~h})$ and four replications. The data were subjected to analysis of variance and represented by the mean \pm standard deviation.

\section{Results and Discussion}

Saline stress caused a reduction on germination, regardless the treatment and osmotic potential. Saline stress treatments in conjunction with inactive SNP and SNP increased the percentage of germination when compared to pure stress (-0.4 and $-0.5 \mathrm{MP})$. There was no significant difference in germination among control treatments (water), SNP and inactive SNP (Figures 1A and B).

These data corroborates studies carried out with the same specie (Silva et al., 2018) and where these substances are acting to bring about this recovery. In Arabidopsis a weakening of the root cell wall was observed 2-4 $\mathrm{h}$ after salt application (Feng et al., 2018), which could be facilitating the entry of the SNP and causing a greater efficacy when applied in conjunction (the stress saline and the donor). 
These results evidenced the effect of nitric oxide and also of cyanide on the improvement of germination when the seeds were exposed to saline stress. Other studies have also shown that the positive effect of nitric oxide donors is not on nitric oxide, as in overcoming seed dormancy of Arabidopsis (Bethke et al., 2006) and on seeds of Clitoria ternatea and Rhyncosia minima (Mullick and Chatterji, 1967).

According to the imbibition curve, germination in the inactive SNP treatment began at $54 \mathrm{~h}$ of soaking, achieving $50 \%$ germination in $60 \mathrm{~h}$, whereas in the control and SNP, germination began at $60 \mathrm{~h}$ of soaking, and at $66 \mathrm{~h}$ the seeds achieved 50\% germination (Figures $2 \mathrm{~A}$ and $\mathrm{B}$ ).

For the treatments with $-0.4 \mathrm{MPa}$ in conjunction with inactive SNP and $-0.4 \mathrm{MPa}$ in conjunction with SNP, germination occurred after $75 \mathrm{~h}$ of soaking and achieved $50 \%$ germination at $120 \mathrm{~h}$ (Figure 2A). For the treatments with -0.5 MPa in conjunction with inactive SNP and -0.5 MPa in conjunction with SNP, seed germination began after $81 \mathrm{~h}$ of soaking and achieved 50\% germination after $180 \mathrm{~h}$ (Figure 2B).

For both salt stresses in conjunction with the SNP and inactive SNP treatments, soaking and root protrusion happened at the same time, confirming the results found in germination,
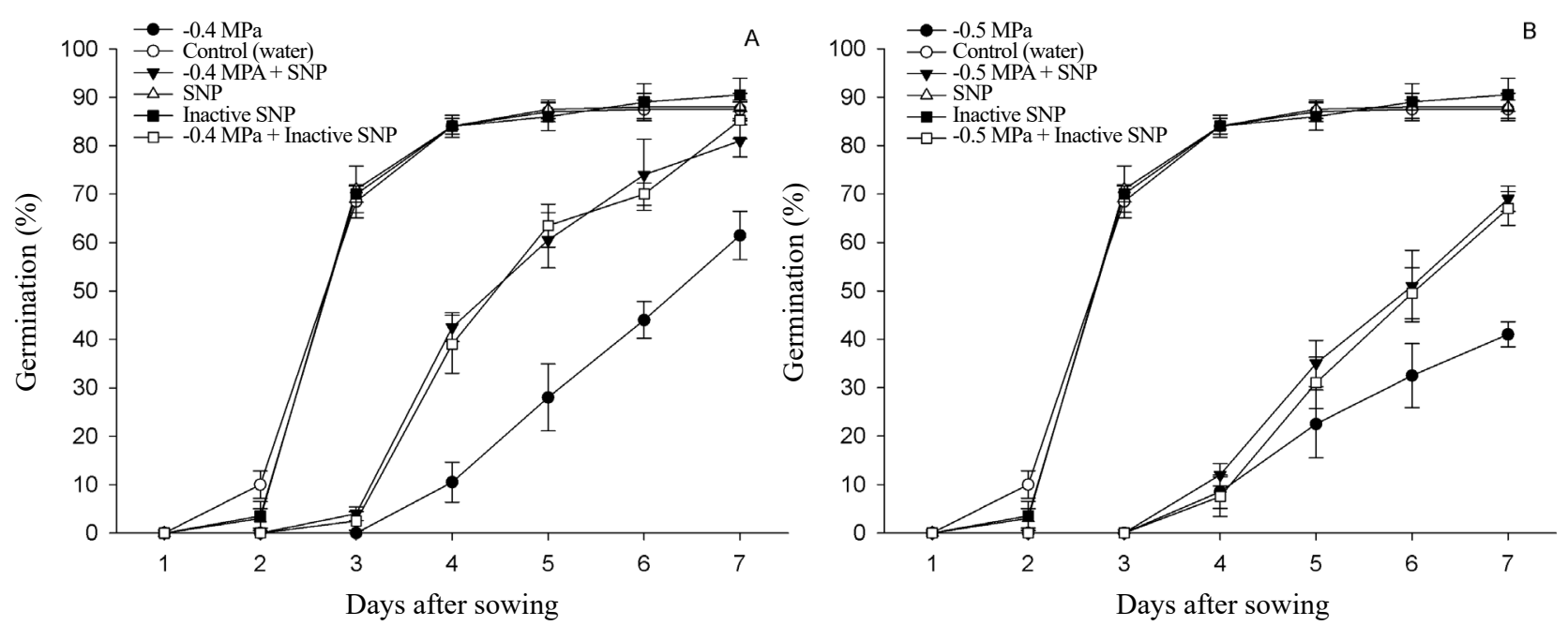

Figure 1. Germination of scarified S. macranthera seeds in different treatments: saline stress -0.4 (A) and -0,5 MPa (B), SNP, inactive SNP and saline stress in conjunction with SNP, inactive SNP and control (water). Bars: standard deviation.
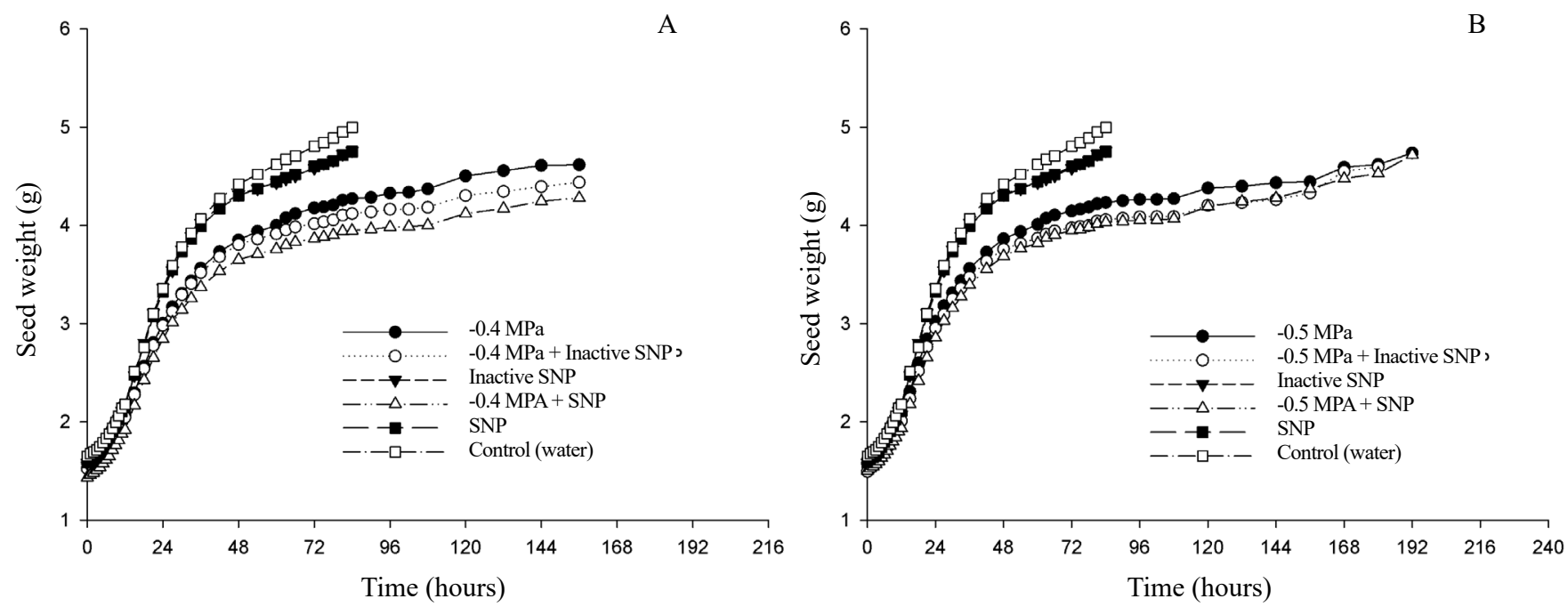

Figure 2. Weight (g) of scarified S. macranthera seeds after different times of soaking in different treatments: saline stress -0.4 (A) and -0,5 MPa(B), SNP, inactive SNP and saline stress in conjunction with SNP, inactive SNP and control (water). Bars: standard deviation. 
where the effect may be from cyanide and not from nitric oxide. The treatment with inactive SNP, that did not contain NO, was soaked and issued roots within the same period as the SNP.

In the salt stresses -0.4 and $-0.5 \mathrm{MPa}$, seed germination began after 84 and $90 \mathrm{~h}$, respectively, and achieved approximately $50 \%$ germination at 144 and $216 \mathrm{~h}$, respectively (Figures 2A and B). In both salt stresses, water absorption was relatively slower since hydration occurred in a more restricted way in the presence of this osmotic agent, making the second phase of germination longer since there was a delay in germination under both potentials.

Effects similar to those caused by the treatment with SNP as germination rate, soaking and root protrusion, were also observed in the treatment with inactive SNP, indicating that the recovery of saline stress during germination in Senna macranthera is to the release of cyanide present in the SNP and not to the nitric oxide.

In regard to antioxidant enzymes, there was an accentuated increase in SOD activity in the initial hours of soaking, regardless of the treatment analyzed (Figures 3A and 4A). This accentuated increase from 0 to $24 \mathrm{~h}$ of soaking may be explained from this enzyme acting in the first line of defense of the cells against the ROS, catalyzing the dismutation reaction of the $\mathrm{O}_{2}$ - to $\mathrm{H}_{2} \mathrm{O}_{2}$ (Sharma et al., 2012).

After that, detoxification of the $\mathrm{H}_{2} \mathrm{O}_{2}$ is performed by enzymes such as CAT and different peroxidases (Gratão et al., 2005). For detoxification of $\mathrm{H}_{2} \mathrm{O}_{2}$, the phenolic compounds can act as antioxidants, donating electrons to the guiacol dependent
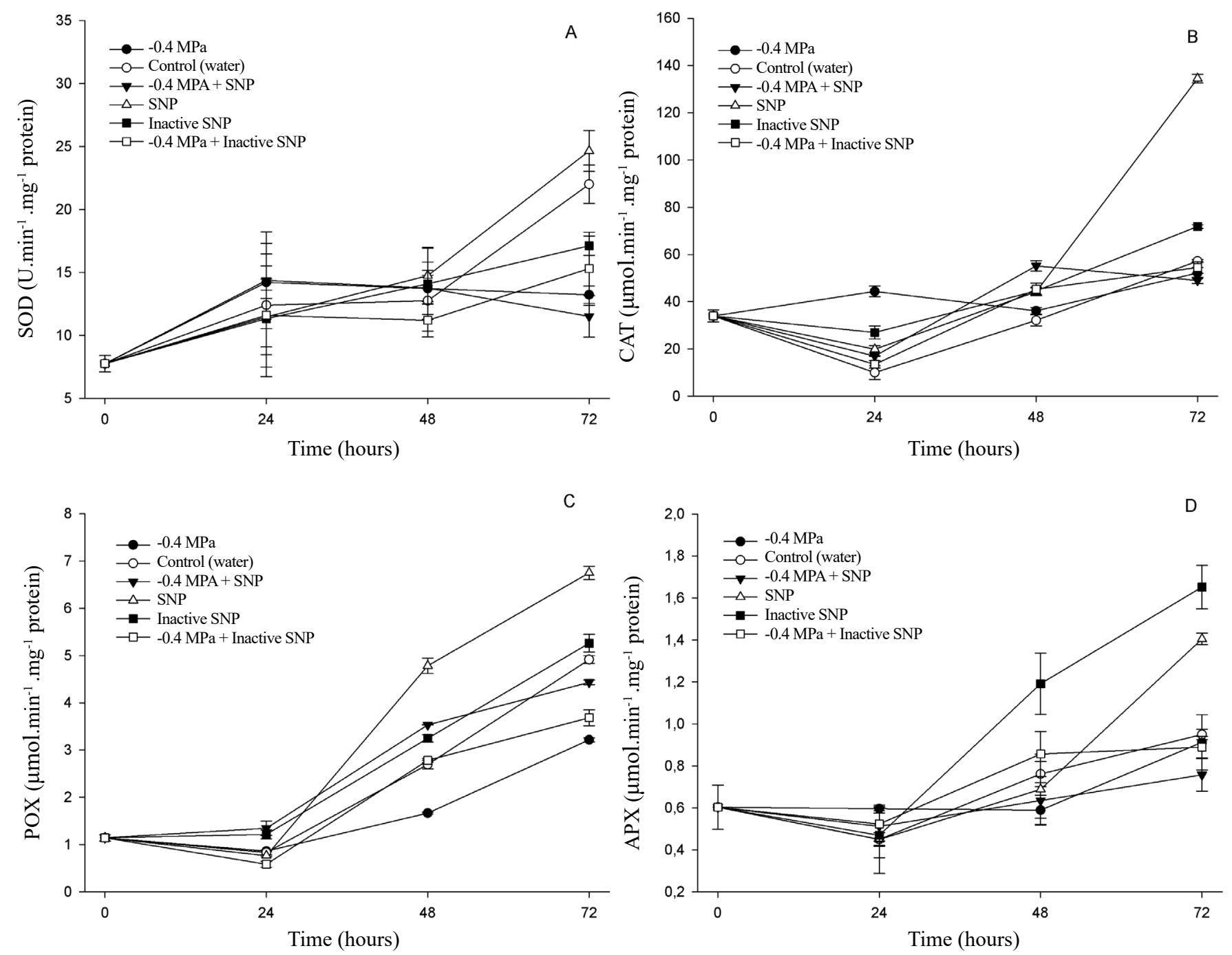

Figure 3. Activity of superoxide dismutase (SOD) (A), catalase (CAT) (B), peroxidase (POX) (C), and ascorbate peroxidase (APX) (D) during germination of $S$. macranthera seeds subjected to saline stress (-0.4 MPa), SNP, inactive SNP and saline stress in conjunction with SNP, inactive SNP and control (water). Bars: standard deviation. 
peroxidases (Sakihama et al., 2002). Confirming these reaction sequences, greater activity of CAT, APX, and POX were mainly observed beginning at $24 \mathrm{~h}$ of soaking seeds (Figures 3 and 4 ).

The enzymes CAT, POX, and APX also exhibited a similar pattern, regardless of the treatment applied, with an increase in activity especially beginning at $24 \mathrm{~h}$ of seed soaking. The treatment with SNP had high activity of all the enzymes analyzed, especially beginning at $48 \mathrm{~h}$ of seed soaking (Figures 3 and 4). In general, the activity of antioxidant enzymes increased under pure salt stress ( -0.4 and $-0.5 \mathrm{MPa})$. However, it was less than under the treatments with SNP and inactive SNP (Figures 3 and 4).

CAT activity showed small increases in the treatments applied in conjunction with the potential of $-0.4 \mathrm{MPa}$. After $48 \mathrm{~h}$ of soaking, there was a slight increase in the SNP treatment without application of salt stress, in a manner similar to SOD (Figure 3B). POX activity exhibited a pattern similar to SOD and CAT, with a sharp increase in activity for the treatment with SNP (Figure 3C). The APX enzyme differed from the other enzymes in relation to the treatment, where the highest activity was observed in the treatment with inactive SNP (Figures 3D and 4D).

CAT activity showed small increases in the treatments applied in conjunction with the potential of $-0.5 \mathrm{MPa}$. After $48 \mathrm{~h}$ of soaking, there was a slight increase only in the SNP treatment without application of salt stress (Figure 4B). The POX and APX activities showed a similar pattern, with an increase beginning at $24 \mathrm{~h}$ of soaking, especially in the SNP and inactive SNP treatment.

In the time of $24 \mathrm{~h}$ of soaking, there was no statistical difference in SOD activity for most of the treatments

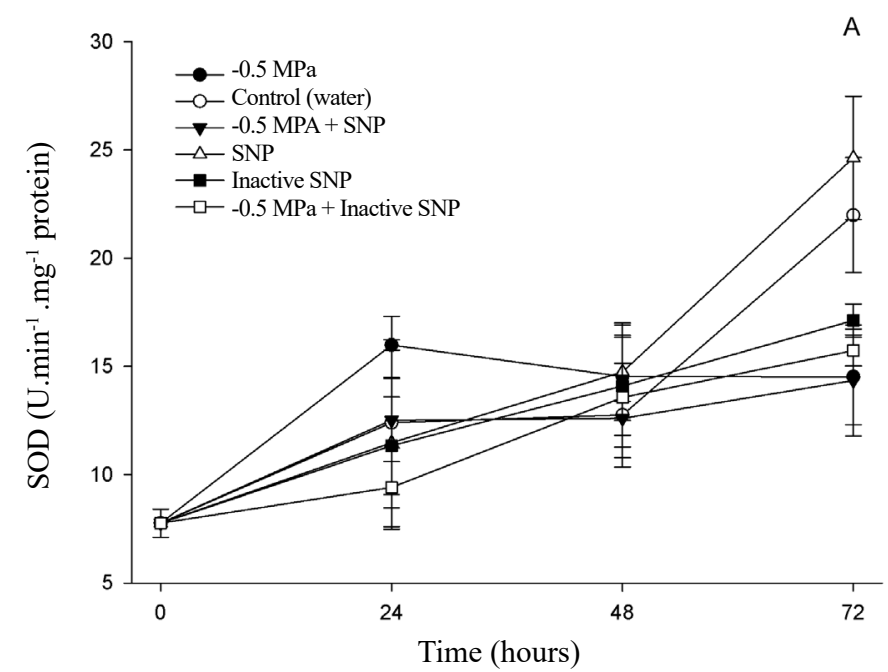

$\mathrm{C}$

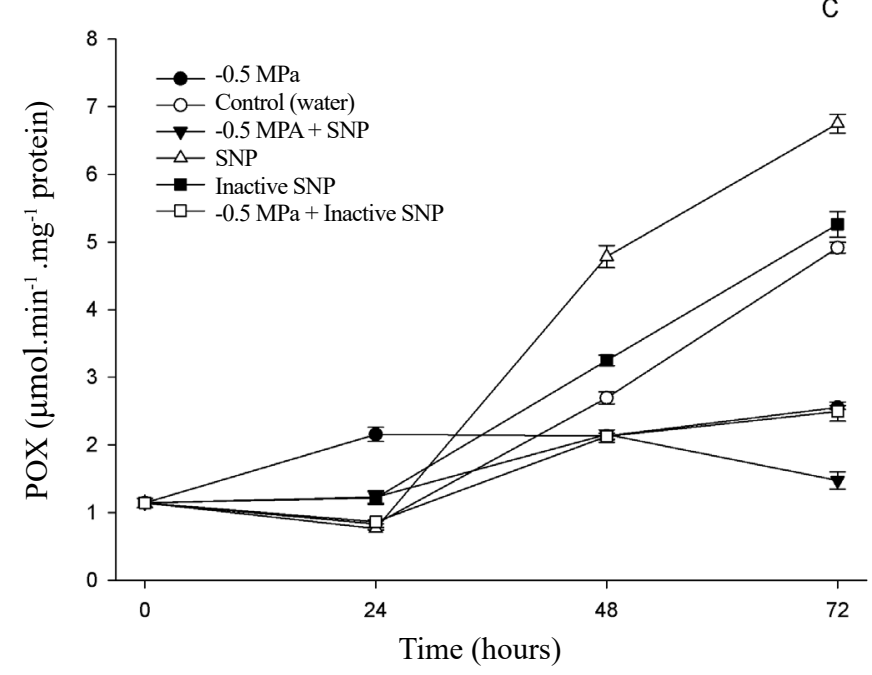

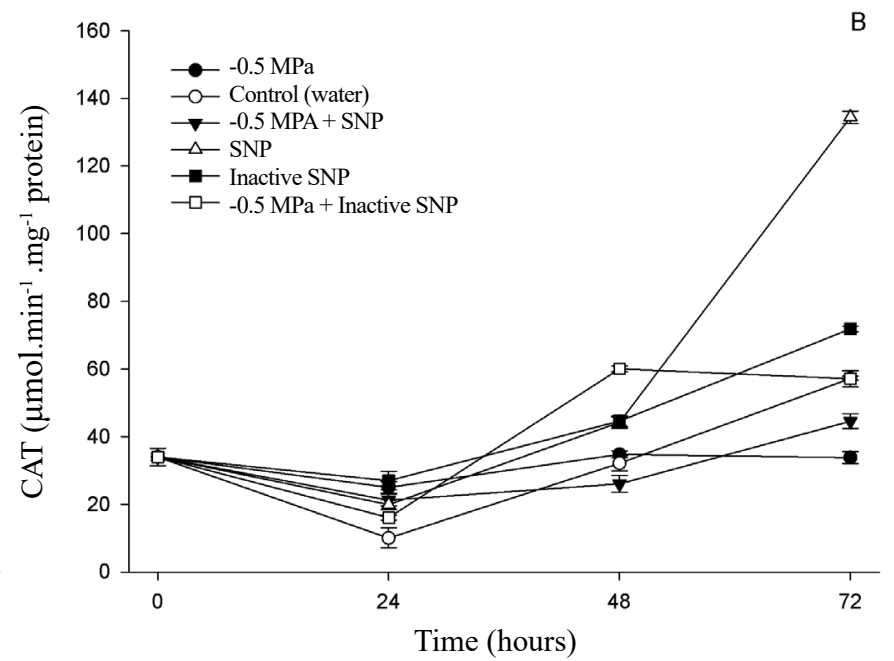

D

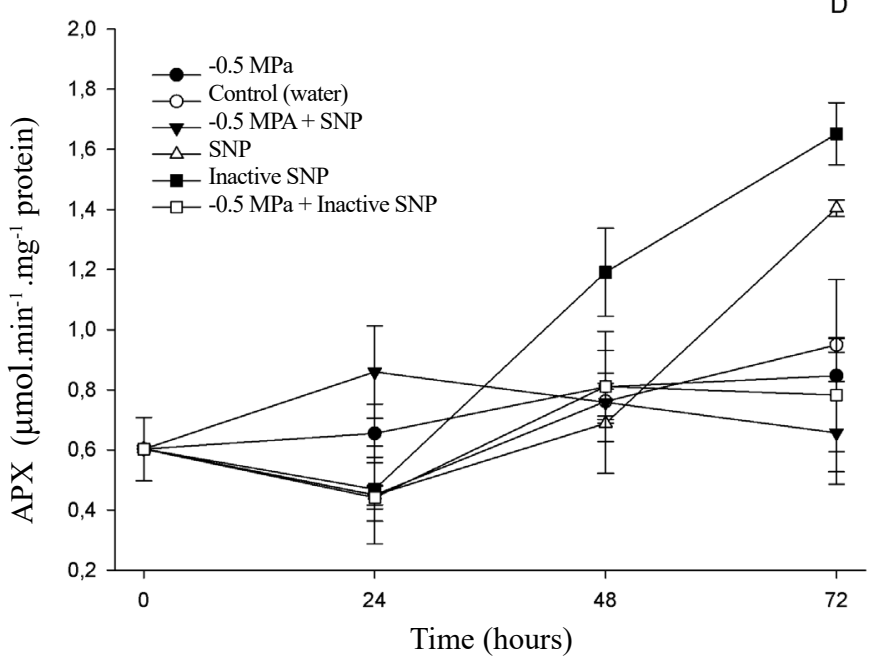

Figure 4. Activity of superoxide dismutase (SOD) (A), catalase (CAT) (B), peroxidase (POX) (C), and ascorbate peroxidase (APX) (D) during germination of S. macranthera seeds subjected to saline stress (-0.5 MPa), SNP, inactive SNP and saline stress in conjunction with SNP, inactive SNP and control (water). Bars: standard deviation. 
evaluated. In this same soaking time, the activity of the POX and APX enzymes were greater in the $-0.5 \mathrm{MPa}$ treatment, and the POX activity differed statistically from the other treatments. At 48 and $72 \mathrm{~h}$ of soaking, the treatment with SNP showed the highest activities of SOD, CAT, POX, and APX.

In general, the increase in antioxidant enzyme activity is mainly connected with the ROS produced, such as the superoxide radicals $\left(\mathrm{O}_{2}^{*}\right)$ and hydrogen peroxide $\left(\mathrm{H}_{2} \mathrm{O}_{2}\right)$. When they are produced in large amounts, they cause oxidation of the cell components, which will lead to oxidative stress (Sies, 2017). The NO released by SNP is considered a versatile signaling molecule that function through interactions with cell targets through redox (Viswanath et al., 2017). As observed, SNP was the treatment that, in general, brought about greater activity of the antioxidant enzymes, especially beginning at $48 \mathrm{~h}$ of soaking.

In a similar way, Wang et al. (2012) observed that the SNP induced an increase in activity of SOD, CAT, POX, and APX in alfalfa seeds (Medicago sativa) subjected to salt stress. These authors attributed such effects to the antioxidant protection system and attenuation of the toxic effects in seeds under stress. Fan et al. (2013) affirms that the protective role of NO under salt stress is at least partially connected with its ability to mediate the activity of antioxidant enzymes and/or direct elimination of the superoxide anion.

Nevertheless, it is noteworthy that the ROS are by products of aerobic metabolism and, at adequate levels in the cells, they can play an essential role in metabolism, such as $\mathrm{H}_{2} \mathrm{O}_{2}$ in cell signaling, tissue restoration, and the seed germination process (Gill and Tuteja, 2010). Within this context, $\mathrm{H}_{2} \mathrm{O}_{2}$ is cited as a molecule that, together with $\mathrm{NO}$, can act within a signal transduction network at cell levels that will result in alleviation of oxidative stress in plants (Qiao et al., 2014). According to Zhang et al. (2009), one of the cell signaling networks through the interaction between $\mathrm{H}_{2} \mathrm{O}_{2}$ and $\mathrm{NO}$ is connected with expression of abscisic acid (ABA) and activity of antioxidant enzymes.

Although the treatment with inactive SNP resulted in an increase in all the antioxidant enzymes, this increase was more prominent in APX (Figures 4C and 4D). Oracz et al. (2009) propose that the ROS play a fundamental role in breaking dormancy in sunflower, acting as secondary messengers of the cyanide.

Gniazdowska et al. (2010) indicate that both NO and cyanide stimulate the accumulation of ROS, leading to greater concentration of ethylene, and they favor the germination process. Krasuska and Gniazdowska (2012) reinforce the importance of interaction between the ROS and these molecules and their relations with the antioxidant enzyme system, affirming that cyanide at specific levels is essential in breaking dormancy of apple embryos, acting as a signaling molecule together with the ROS. The increase in enzyme activity is related to the toxic stress caused by saline stress, where the reactive oxygen species increase and consequently increase the activity of these enzymes. The inactive SNP and SNP in the present study would be an inducing activity of the antioxidant enzymes, which would reduce the concentration of $\mathrm{H}_{2} \mathrm{O}_{2}$ in the seeds caused by saline stress.

Thus, the higher activity of the antioxidant enzymes in the treatments with SNP and inactive SNP may be related to these factors, since they modulate ROS production and reinforce antioxidant enzyme activity, interacting with high levels of ROS and acting as signaling molecules and antioxidants (Singh et al., 2008; Saxena and Shekhawat, 2013).

For all the treatments, the malonaldehyde (MDA) content decreased throughout the germination process, especially beginning at $0 \mathrm{~h}$ of soaking (Figure 5). The treatments with pure salt stress $(-0.4$ and $-0.5 \mathrm{MPa})$ exhibited higher MDA content at 24 and $48 \mathrm{~h}$ of soaking, indicating greater lipid peroxidation, showing the effect of excess salts affecting membrane integrity. At these same soaking times, the MDA content was less in the treatment with SNP, indicating lower peroxidation of lipids through release of NO. For the $72 \mathrm{~h}$ soaking time, differences were not observed among the treatments (Figure 5). Similar results are reported by Ahmad et al. (2016).

According to Huaifu etal. (2007), NO has the ability to restore and attenuate the damage in membranes through reduction in permeability and peroxidation of lipids. Nevertheless, membrane changes related to lipid peroxidation involve a complex network involving other biochemical mechanisms, controlled by hormones such as ABA (Monteiro et al., 2012).

Just as for MDA, in all the treatments, there was a decrease in total proteins from the first few hours after the beginning of soaking up to $72 \mathrm{~h}$. After $24 \mathrm{~h}$ of soaking, significant differences were observed among the treatments, and the most expressive decrease was observed in the -0.5 MPa treatment (Figure 6).

Unlike that observed for antioxidant enzyme activity and for MDA content, no statistical difference was observed of the treatment with SNP in relation to other treatments at any of the soaking times for total proteins (Figure 6). This reduction in all the treatments over the germination process indicates that this reserve is being used. In legume seeds, mobilization of reserve proteins begins with embryo development, supplying the nitrogen necessary for seedling growth (Buckeridge et al., 2004). In an experiment with $S$. macranthera, an expressive increase was observed in 
glucose content after $72 \mathrm{~h}$ of soaking, which may be credited to metabolism of other reserves, such as lipids or proteins, which are used by the embryo as an energy source and substrate for cell structures (Borges et al., 2002).

Nevertheless, this initial consumption of reserve protein varies according to the species, as observed for Caesalpinia peltophoroides, for which protein contents decreased from the beginning of soaking (Borges et al., 2005; Corte et al., 2006).
Based on the results, where both salt stresses (-0.4 and -0.5 $\mathrm{MPa}$ ) in conjunction with the SNP and inactive SNP treatments, showed effects similar in root protrusion and germination rate, indicating that these effects were related to the release of the cyanide present in sodium nitroprusside. The cyanide favored germination, reducing lipid peroxidation and increasing the activity of the antioxidant enzymes, which would reduce the concentration of $\mathrm{H}_{2} \mathrm{O}_{2}$ in the seeds caused by saline stress.
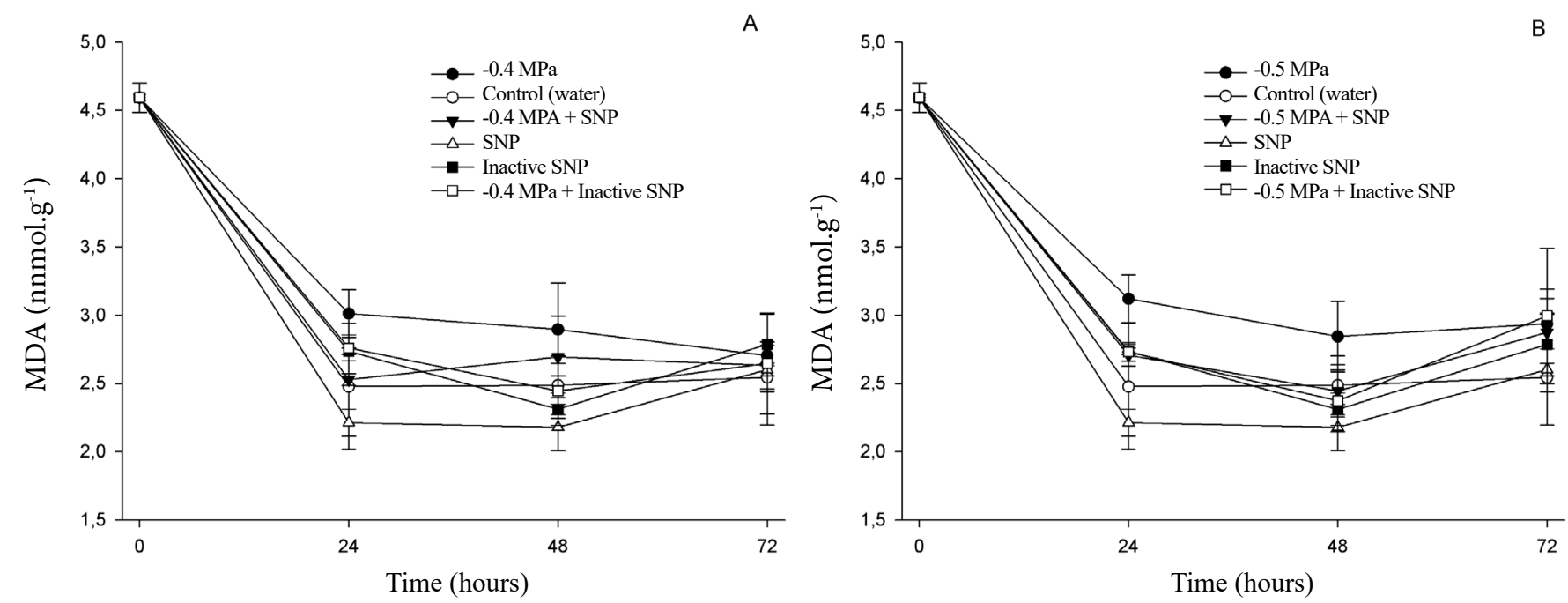

Figure 5. Lipid peroxidation (MDA) of scarified $S$. macranthera seeds subjected to saline stress -0.4 (A) and -0.5 MPa (B), SNP, inactive SNP and saline stress in conjunction with SNP, inactive SNP and control (water). Bars: standard deviation.
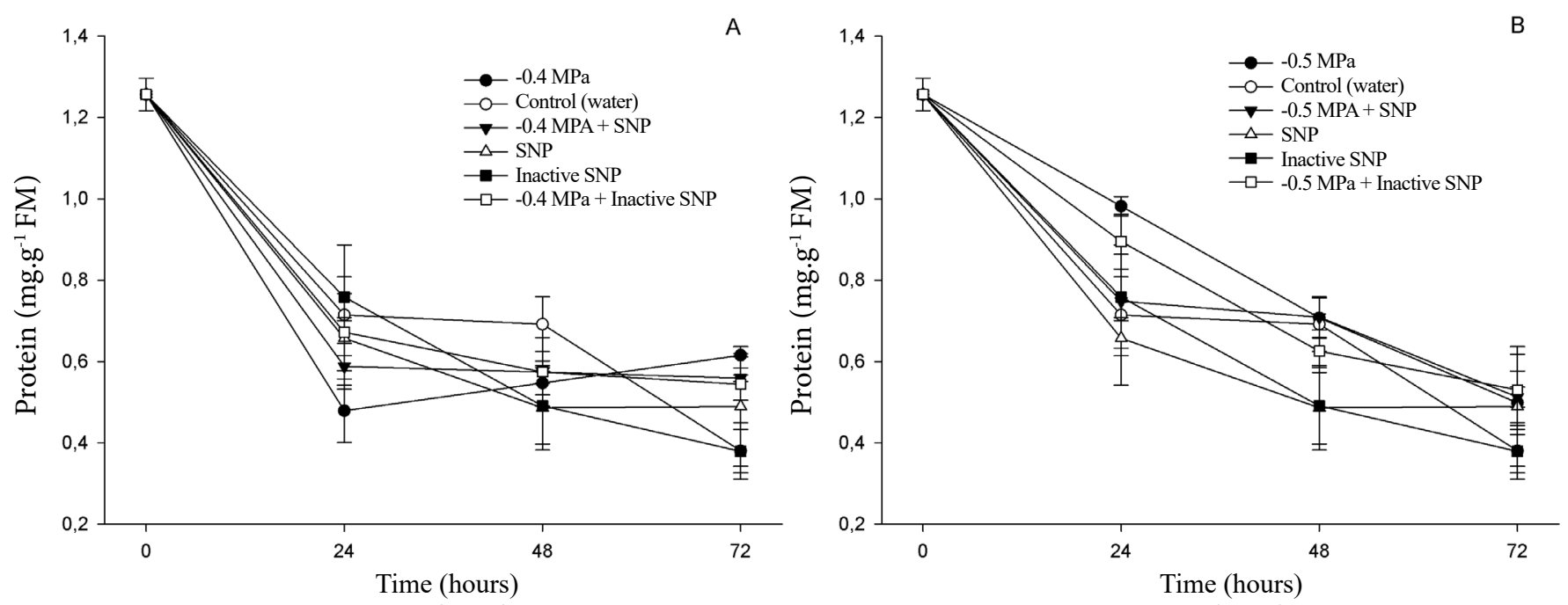

Figure 6. Total proteins of scarified S. macranthera seeds subjected to saline stress -0.4 (A) and $-0.5 \mathrm{MPa}$ (B), SNP, inactive SNP and saline stress in conjunction with SNP, inactive SNP and control (water). Bars: standard deviation.

\section{Conclusions}

The sodium nitroprusside (SNP) improves the germination of Senna macranthera seeds under salt stress conditions, through release of cyanide. The cyanide favors the germination of Senna macranthera contributing to reduction in lipid 
peroxidation and to increase in antioxidant enzymes activity.

\section{Acknowledgments}

Our thanks to Conselho Nacional de Desenvolvimento Cientifico e Tecnológico (CNPq), Coordenação de Aperfeiçoamento de Pessoal de Nivel Superior (CAPES) and Fundação de Amparo à Pesquisa do Estado de Minas Gerais (FAPEMIG).

\section{References}

AHMAD, P.; ABDEL LATEF, A.A.; HASHEM, A.; ABD_ALLAH, E.F.; GUCEL, S.; TRAN, L.S.P. Nitric oxide mitigates salt stress by regulating levels of osmolytes and antioxidant enzymes in Chickpea. Frontiers in Plant Science, v.7, p.347, 2016. https://www.ncbi.nlm. nih.gov/pmc/articles/PMC4814448/

ANDERSON, M.D.; PRASAD, T.K.; STEWART, C.R. Changes in isozyme profiles of catalase, peroxidase, and glutathione reductase during acclimation to chilling in mesocotylus of maize seedlings. Plant Physiology, v.109, p.1247-1257, 1995. https://www.ncbi.nlm. nih.gov/pmc/articles/PMC157657/

BEAUCHAMP, C.; FRIDOVICH, I. Superoxide Dismutase: Improved assays and an assay applicable to acrylamide gels. Analytical Biochemistry, v.44, p.276-287, 1971. https://www.sciencedirect.com/science/article/ pii/0003269771903708?via\%3Dihub

BEGARA-MORALES, J.C.; SÁNCHEZ-CALVO, B.; CHAKI, M.; VALDERRAMA, R.; MATA-PÉREZ, C.; LÓPEZ-JARAMILLO, J.; PADILLA, M.N.; CARRERAS, A.; CORPAS, F.J.; BARROSO, J.B. Dual regulation of cytosolic ascorbate peroxidase (APX) by tyrosine nitration and S-nitrosylation. Journal of Experimental Botany, v.65, p.527-538, 2014. https://www.ncbi.nlm.nih.gov/pubmed/24288182

BETHKE, P.C.; LIBOUREL, I.G.L.; JONES, R.L. Nitric oxide reduces seed dormancy in Arabidopsis. Journal of Experimental Botany, v.57, n.3, p.517-526, 2006. https://academic.oup.com/jxb/ article $/ 57 / 3 / 517 / 510715$

BORGES, E.E.L.; BORGES, R.C.G.; SOARES, C.P.B.; PEREZ, S.C.J.G.A. Crescimento e mobilização de carboidrato em embrião de sementes de fedegoso (Senna macranthera Irwin et Barneby) durante a germinação. Cerne, v.8, p.69-76, 2002. http://www. redalyc.org/pdf/744/74408107.pdf

BORGES, E.E.L.; REZENDE, S.T.; BORGES, R.C.G.; PEREZ, S.C.J.G.A. Caracterização de alfagalactosidase e sua relação com germinação das sementes de Caesalpinia peltophoroides (Leguminosae Caesalpinioideae). Revista Arvore, v.29, p.525-533, 2005. http://www.scielo.br/scielo.php?script=sci_ abstract\&pid=S0100-67622005000400004\&lng=pt\&nrm=iso

BRADFORD, M.M. A rapid and sensitive method for the quantitation of microgram quantities of protein utilizing the principle of protein-dye binding. Analytical Biochemistry, v.72, p.248-254, 1976. https://www.sciencedirect.com/science/article/ pii/0003269776905273?via\%3Dihub
BUCKERIDGE, M.S.; SANTOS, H.P.; TINÉ, M.A.S.; AIDAR, M.P.M. Mobilização de reservas. In: FERREIRA, A.G.; BORGHETTI, F. Germinação: do básico ao aplicado. Artmed: Porto Alegre, 2004. p.163-185.

CORPAS, F.J.; LETERRIER, M.; VALDERRAMA, R.; AIRAKI, M.; CHAKI, M.; PALMA, J.M.; BARROSO, J.B. Nitric oxide imbalance provokes a nitrosative response in plants under abiotic stress. Plant Science, v.181, p.604-611, 2011. https://www.ncbi.nlm. nih.gov/pubmed/21893257

CORTE, V.B.; BORGES, E.E.L.; PONTES, C.A.; LEITE, I.T.A.; VENTRELLA, M.C.; MATHIAS, A.A. Mobilização de reservas durante a germinação das sementes e crescimento das plântulas de Caesalpinia peltophoroides Benth. (Leguminosae-Caesalpinoideae). Revista Árvore, v.30, p.941-949, 2006. http://www.scielo.br/scielo. php?pid=S0100-67622006000600009\&script $=$ sci_abstract\&tlng $=$ pt

DEL LONGO, O.T.; GONZÁLEZ, A.; PASTORI, G.M.; TRIPPI, V.S. Antioxidant defenses under hyperoxygenic and hyperosmotic conditions in leaves of two lines of maize with differential sensitivity to drought. Plant Cell Physiology, v.34, p.1023-1028, 1993. https:// academic.oup.com/pcp/article-abstract/34/7/1023/1810685?redirect edFrom $=$ PDF

FAN, H.F.; DU, C.X.; DING, L.; XU, Y.L. Effects of nitric oxide on the germination of cucumber seeds and antioxidant enzymes under salinity stress. Acta Physiology Plant, v.35, p. 2707-2719, 2013. http://link.springer.com/article/10.1007\%2Fs11738-013-1303-0\#

FENG, W.; KITA, D.; PEAUCELLE, A.; CARTWRIGHT, H.N.; DOAN, V.; DUAN, Q.; LIU, M.C.; MAMAN, J.; STEINHORST, L.; SCHMITZ-THOM, I.; YVON, R.; KUDLA, J.; WU, H.M.; CHEUNG, A.Y.; DINNENY, J.R. The FERONIA receptor kinase maintains cell-wall integrity during salt stress through $\mathrm{Ca}^{2+}$ signaling. Current Biology, v.28, p.666-675, 2018. https://www.ncbi.nlm.nih. gov/pubmed/29456142

GIANNOPOLITIS, C.N.; RIES, S.K. Superoxide dismutases. Plant Physiology, v.59, p.309-314, 1977. https://www.ncbi.nlm.nih.gov/ pmc/articles/PMC542388/

GILL, S.S.; TUTEJA, N. Reactive oxygen species and antioxidant machinery in abiotic stress tolerance in crop plants. Plant Physiology and Biochemistry, v.48, p.909-930, 2010. https://www.ncbi.nlm.nih. gov/pubmed/20870416

GNIAZDOWSKA, A.; KRASUSKA, U.; BOGATEK, R. Dormancy removal in apple embryos by nitric oxide or cyanide involves modifications in ethylene biosynthetic pathway. Planta, v.232, p.13971407, 2010. https://www.ncbi.nlm.nih.gov/pubmed/20830596

GRATÃO, P.L.; POLLE, A.; LEA, P.J.; AZEVEDO, R.A. Making the life of heavy metal-stressed plants a little easier. Functional Plant Biology, v.32, p.481-494, 2005. https://www.researchgate. net/publication/262995774_Making_the_Life_of_Heavy_MetalStressed_Plants_a_Little_Easier

GUPTA, B.; HUANG, B. Mechanism of salinity tolerance in plants: physiological, biochemical, and molecular characterization. International Journal of Genomics, v.2014, p.1-18, 2014. http:// dx.doi.org/10.1155/2014/701596 
HAVIR, E.A.; MCHALE, N.A. Biochemical and developmental characterization of multiple forms of catalase in tobacco leaves. Plant Physiology, v.84, p.450-455, 1987. https://www.ncbi.nlm.nih. gov/pubmed/16665461

HEATH, R.L.; PACKER, L. Photoperoxidation in isolated chloroplasts: I. Kinetics and stoichometry of fatty acid peroxidation. Archives of Biochemistry and Biophysics, v.125, p.189-198, 1968. https://www. sciencedirect.com/science/article/pii/0003986168906541?via\%3Dihub

HUAIFU, F.; SHIRONG, G.; YANSHENG, J.; RUNHUA, Z.; JUAN, L. Effects of exogenous nitric oxide on growth, active oxygen species metabolism, and photosynthetic characteristics in cucumber seedlings under $\mathrm{NaCl}$ stress. Frontiers of Agricuture in China, v.1, p.308-314, 2007. https://link.springer.com/ article/10.1007\%2Fs11703-007-0052-5

KAR, M.; MISHRA, D. Catalase, peroxidase, and polyphenoloxidase activities during rice leaf senescence. Plant Physiology, v.57, p.315319, 1976. https://www.ncbi.nlm.nih.gov/pmc/articles/PMC542015/

KOPYRA, M.; GWÓZ'DZ', E.A. Nitric oxide stimulates seed germination and counteracts the inhibitory effect of heavy metals and salinity on root growth of Lupinus luteus. Plant Physiology Biochemistry, v.41, p.1011-1017, 2003. http://www.sciencedirect. com/science/article/pii/S098194280300175X

KRASUSKA, U.; GNIAZDOWSKA, A. Nitric oxide and hydrogen cyanide as regulating factors of enzymatic antioxidant system in germinating apple embryos. Acta Physiologiae Plantarum, v.34, p.683-692, 2012. https://link.springer.com/article/10.1007/s11738011-0868-8

MAEHLEY, A.C.; CHANCE, B. Assay of catalases and peroxidases. Methods in Enzymology, v.2, p.764-775, 1955. https://www.ncbi. nlm.nih.gov/pubmed/13193536

MANAI, J.; KALAI, T.; GOUIA, H.; CORPAS, F.J. Exogenous nitric oxide (NO) ameliorates salinity-induced oxidative stress in tomato (Solanum lycopersicum) plants. Journal of Soil Science and Plant Nutrition, v.14, p.433-446, 2014. https://scielo.conicyt.cl/ scielo.php?script=sci_arttext\&pid=S0718-95162014000200014

MONTEIRO, C.C.; ROLÃO, M.B.; FRANCO, M.R.; PETERS, L.P.; CIA, M.C.; CAPALDI, F.R.; CARVALHO, R.F.; GRATÃO, P.L.; ROSSI, M.L.; MARTINELLI, A.P.; PERES, L.E.P.; AZEVEDO, R.A. Biochemical and histological characterization of tomato mutants. Anais da Academia Brasileira de Ciências, v.84, p.573-585, 2012. http://www.scielo.br/scielo.php?script=sci_ abstract\&pid=S0001-37652012000200025\&lng=pt\&nrm=iso

MULLICK, P.; CHATTERJI, U.N. Effect of sodium cyanide on germination of two leguminous seeds. Österreichische botanische Zeitschrift, v.114, n.1, p.88-91, 1967. https://www.jstor.org/stable/ i40132568

NASIBI, F.; KALANTARI, K.M. Influence of nitric oxide in protection of tomato seedling against oxidative stress induced by osmotic stress. Acta Physiologiae Plantarum, v.31, p.1037-1044, 2009. https://link.springer.com/article/10.1007/s11738-009-0323-2
ORACZ, K.; EL-MAAROUF-BOUTEAU, H.; KRANNER, I.; BOGATEK, R.; CORBINEAU, F.; BAILLY, C. The mechanisms involved in seed dormancy alleviation by hydrogen cyanide unravel the role of reactive oxygen species as key factors of cellular signaling during germination. Plant Physiology, v.150, p.494-505, 2009. http://www.plantphysiol.org/content/150/1/494

PEIXOTO, P.H.P.; CAMBRAIA, J.; SANTANA, R.; MOSQUIM, P.R.; MOREIRA, M.A. Aluminum effects on lipid peroxidation and on activities of enzymes of oxidative metabolism in sorghum. Revista Brasileira de Fisiologia Vegetal, v.11, p.137-143, 1999. https://www.researchgate.net/publication/267338431_aluminum effects_on_lipid_peroxidation_and_on_the_activities_of_enzymes_ of_oxidative_metabolism_in_sorghum

QIAO, W.; LI, C.; FAN, L.M. Cross-talk between nitric oxide and hydrogen peroxide in plant responses to abiotic stresses. Environmental an Experimental Botany, v.100, p.84-93, 2014. https:// www.sciencedirect.com/science/article/pii/S0098847213002256

SAKIHAMA, Y.; COHEN, M.F.; GRACE, S.C.; YAMASAKI, H. Plant phenolic antioxidant and prooxidant activities: phenolicsinduced oxidative damage mediated by metals in plants. Toxicology, v.177, p.67-80, 2002. https://www.ncbi.nlm.nih.gov/ pubmed/12126796

SAXENA, I.; SHEKHAWAT, G. Nitric oxide (NO) in alleviation of heavy metal induced phytotoxicity and its role in protein nitration. Nitric Oxide, v.32, p.13-20, 2013. https://www.ncbi.nlm.nih.gov/ pubmed/23545403

SECKIN, B.; TURKAN, I.; SEKMEN, A.H.; OZFIDAN, C. The role of antioxidant defense systems at differential salt tolerance of Hordeum marinum Huds. (sea barleygrass) and Hordeum vulgare L. (cultivated barley). Environmental of Experimental Botany, v.69, p.76-85, 2010. https:/www.sciencedirect.com/science/article/pii/ S0098847210000389

SHARMA, P.; BLUSHAN, J.; DUBEY, R.S.; PESSARAKLI, M. Reactive oxygen species, oxidative damage, and antioxidative defense mechanism in plants under stressful conditions. Journal of Botany, v.12, p. 1-26, 2012. https://www.hindawi.com/journals/ $\mathrm{jb} / 2012 / 217037 /$

SIES, H. Hydrogen peroxide as a central redox signaling molecule in physiological oxidative stress: Oxidative eustress. Redox Biology, v.11, p.613-619, 2017. https://www.ncbi.nlm.nih.gov/pmc/articles/ PMC5256672/

SILVA, A.L.; DIAS, D.C.F.S.; BORGES, E.E.L.; RIBEIRO, D.M.; SILVA, L.J. Effect of sodium nitroprusside (SNP) on the germination of Senna macranthera seeds (DC. ex Collad.) H. S. Irwin \& Baneby under salt stress. Journal of Seed Science, v.37, n.4, p.236-243, 2015. http://www.scielo.br/scielo.php?script=sci_ arttext\&pid $=$ S2317-15372015000400236

SILVA, A.L.; PINHEIRO, D.T.; BORGES, E.E.L.; SILVA, L.J.; DIAS, D.C.F.S. Salinity tolerance in Senna macranthera (DC. ex Collad.) H. S. Irwin \& Barneby seeds with sodium nitroprusside (SNP) promoted by cyanide. Journal of Seed Science, v.40, n.3, p.323-330, 2018. http://www.scielo.br/scielo.php?script=sci_ arttext\&pid=S2317-15372018000300323 
SIMAEI, M.; KHAVARI-NEJAD, R.A.; BERNARD, F. Exogenous application of salicylic acid and nitric oxide on the ionic contents and enzymatic activities in NaCl-stressed soybean plants. American Journal of Plant Sciences, v.3, n.10, p.1495-1503, 2012. http://www. scirp.org/journal/PaperInformation.aspx?PaperID=24169

SINGH, H.P.; BATISH, D.R.; KAUR, G.; ARORA, K.; KOHLI, R.K. Nitric oxide (as sodium nitroprusside) supplementation ameliorates $\mathrm{Cd}$ toxicity in hydroponically grown wheat roots. Environmental an Experimental Botany, v.63, p.158-167, 2008. https://www. sciencedirect.com/science/article/pii/S0098847207002596

VISWANATH, K.K.; PALAKA, B.K.; AMPASALA, D.R. Alleviation of nickel toxicity in finger millet (Eleusine coracana L.) germinating seedlings by exogenous application of salicylic acid and nitric oxide. The Crop Journal, v.5, p.240-250, 2017. https://www. sciencedirect.com/science/article/pii/S2214514116301088
WANG, Y.; LI, L.; CUI, W.; XU, S.; SHEN, W.; WANG, R. Hydrogen sulfide enhances alfalfa (Medicago sativa) tolerance against salinity during seed germination by nitric oxide pathway. Plant Soil, v.351, p.107119, 2012. https://link.springer.com/article/10.1007/s11104-011-0936-2

ZHANG, Y.; TAN, J.; GUO, Z.; LU, S.; HE, S.; SHU, W.; ZHOU, B. Increased abscisic acid levels in transgenic tobacco over-expressing 9 cis-epoxycarotenoid dioxygenase influence $\mathrm{H}_{2} \mathrm{O}_{2}$ and $\mathrm{NO}$ production and antioxidant defences. Plant, Cell \& Environment, v.32, n.5, p.509-519, 2009. https://www.ncbi.nlm.nih.gov/pubmed/19183289 